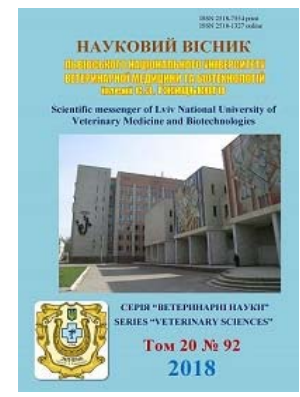

\author{
Науковий вісник Дьвівського національного університету \\ ветеринарної медицини та біотехнологій імені С.З. Гжицького
}

\author{
Scientific Messenger of Lviv National University \\ of Veterinary Medicine and Biotechnologies
}

UDC 619:636.7. 619:616-091

\title{
Histological and histochemical changes in the dogs liver at poisoning isoniazid
}

\author{
H.I. Kotsyumbas, N.P. Vretsona
}

Stepan Gzhytskyi National University of Veterinary Medicine and Biotechnologies Lviv, Ukraine

Article info

Received 05.11.2018

Received in revised form 04.12 .2018

Accepted 05.12.2018

Stepan Gzhytskyi National University of Veterinary Medicine and Biotechnologies Lviv,

Pekarska Str., 50, Lviv, 79010, Ukraine.

Tel.: +38-067-373-83-39.

E-mail: nataliya.vretsona@gmail.com
Kotsyumbas, H.I., \& Vretsona, N.P. (2018). Histological and histochemical changes in the dogs liver at poisoning isoniazid. Scientific Messenger of Lviv National University of Veterinary Medicine and Biotechnologies, 20(92), 197-202. doi: 10.32718/nvlvet9241

The article presents the results of macroscopic, histological and histochemical studies of dogs liver for isoniazid poisoning. The pathoanatomical section of 18 corpses of dogs of all ages and breeds has been carried out, fragments of different parts of the liver have been selected. Liver samples were fixed in a $10 \%$ aqueous solution of neutral formalin, Carnoua and Buena liquids. The dewatering in ethanol of increasing concentration was conducted, sealed in paraffin. The sections were made on a microtome MC-2 in the thickness of 7 microns, stained with hematoxylin and eosin, according to the technique of McManus, Pearles. The produced histoplasts were examined under a light microscope Leica DM 2500 (Switzerland), photocycled by the Leica DFC450C camera using the Leica Application Suite Version 4.4 software. Macroscopically, the liver in all studied corpses of dogs is enlarged, the edges are rounded, inhomogeneously colored (from dark cherry to light brown), loose consistency, a light bloody fluid is secreted on the cut, the structure of the organ is smoothed out. Optically light in the liver of most dogs for isoniazid poisoning noted profound violations of all structures of angioarhitectonics, stroma and parenchyma of the organ. Prevalent non-fibrotic changes in the endothelium, dilatation and deformation of central veins and sinusoidal mesh with the formation of cells filled with blood plasma. The expressed dystrophy and necrobiosis of hepatocytes and Kupferov cells were combined with erythrocyte hemolysis, which was reflected by the deposition of hemosiderin in the cytoplasm of macrophages and bilirubin in hepatocytes. In rare cases, in the liver of poisoned dogs, acute congestive hyperemia, diapedeous hemorrhages in peripartal regions and non-fibrotic changes in hepatocytes were observed. On the basis of conducted morphological studies, it can be argued that derivatives of isoniazid compounds in the dog's organism have a pronounced hepatotoxic effect characterized by a severe violation of blood and lymph microcirculation and all metabolic processes in liver cells, manifested by dystrophic-non-fibrotic processes in the body.

Key words: isoniazid, dogs, poisoning, liver, histology, histochemistry.

\section{Гістологічні та гістохімічні зміни в печінці собак за отрусння ізоніазидом}

\author{
Г.І. Коцюмбас, Н.П. Врецьона
}

Львівський національний університет ветеринарної медицини та біотехнологій імені. С.3. Гжицького, м. Львів, Україна

У статті представлені результати макроскопічних, гістологічних та гістохімічних досліджень печінки собак за отруєння ізоніазидом. Проведено патологоанатомічний розтин 18 трупів собак різного віку та породи, відібрано фрагменти різних часток печінки. Взіриі печінки фіксували в 10 \% водному розчині нейтрального формаліну, рідині Карнуа і Буена. Проводили зневоднення в етанолі зростаючої концентрації, ущільнювали в парафіні. Виготовляли зрізи на мікротомі МС-2 товщчиною 7 мкм, фарбували гематоксиліном та еозином, за методикою Мак-Мануса, Перлса. Виготовлені гістопрепарати розглядали під світловим мікроскопом Leica DM 2500 (Switzerland), фотофіксаиію здійснювали фотокамерою Lеіса DFC450С з використанням програмного забезпечення Leica Application Suite Version 4.4. Макроскопічно печінка у всіх досліджуваних трупів собак збільшена, краї заокруглені, неоднорідно забарвлена (від темно-вишневого до світло - коричневого кольору), в'ялої консистениї, на розрізі виділялась світла кров'яниста рідина, структура органу згладжена. Світлооптично у печіниі більшості собак за отруєння ізоніазидом відзначали глибокі порушення всіх структур ангіоархітектоніки, строми і паренхіми органу. Превалювали некробіотичні зміни ендотелію, дилатація і деформація центральних вен та синусоїдальної сітки з утворенням осередків, заповнених плазмою крові. Виражена 
дистрофія і некробіоз гепатоцитів та купферівських клітин поєднувались із гемолізом еритрочитів, ичо відобразилось відкладанням гемосидерину в циитоплазму макрофагів та білірубіну в гепатоцитах. У поодиноких випадках у печінці отруєних собак, виявляли гостру застійну гіперемію, діапедезні крововиливи у перипортальнах ділянках та некробіотичні зміни в гепатоцитах. На основі проведених морфологічних досліджень можна стверджувати, щзо похідні сполуки ізоніазиду в організмі собак володіють вираженою гепатотоксичною дією, яка характеризувалась різким порушенням мікроциркуляції крові $і$ лімфи та усіх обмінних процесів у клітинах печінки, щуо виразилось дистрофічно-некробіотичними процесами в органі.

Ключові слова: ізоніазид, собаки, отруєння, печінка, гістологія, гістохімія.

Вступ

Ізоніазид (гідразид ізонікотинової кислоти, ГІНК) - туберкулостатичний препарат, який був синтезований ще у 1926 р. Качугіним А.Т., а створений на його основі лікарський препарат став відомим як “тубазид" (Meyer and Mally, 1912). Даний лікарський препарат широко представлений на ринку України, легкодоступний, вільно продається в мережі аптек без рецепта і використовується для лікування людей від туберкульозу. Останніми роками в Україні для зменшення кількості безпритульних собак несанкціонованими методами люди стали застосовувати ізоніазид для їх отруєння. Виявляється, що для собаки, яка важить $<10$ кг, достатньо однієї таблетки ізоніазиду (300 мг), яка спричиняє ознаки отруєння і призводить до серйозних структурно-функціональних порушень внутрішніх органів та потенційної смерті (Schmid et al., 2017; Kotsyumbas et al., 2018).

Метаболічне перетворення отрути в організмі відбувається за рахунок мікросомальних ферментів печінки, які відіграють особливу роль у детоксикації багатьох отруйних речовин. У 1952 p. Roth i Manthei вивчаючи метаболізм ізоніазиду в організмі виявили, що біотрансформація ГІНК відбувається двома шляхами: шляхом гідролізу, в результаті чого утворюється ізонікотинова кислота та гідразин, який надалі піддається перетворенням 3 утворенням таких сполук як ацетилізоніазид та моноацетилгідразин, що проявляють гепатотокчину дію; другий шлях - біотрансформації ГІНК - ацетилювання під час якого утворюється $\mathrm{N}$-ацетилізоніацид (Hirtz, 1968). У собак переважає перший шлях біотрансформації (гідроліз) внаслідок недостатньої активності Nацетилтрансферази. Оскільки печінкова Nацетилтрансфераза собак володіє низькою активністю - це зумовлює високу гепатотоксичну дію та розвиток гострого отруєння.

Метою нашої роботи було вивчення особливостей морфологічних змін в печінці собак за отруєння ізоніазидом.

\section{Матеріал і методи досліджень}

Проведено патологоанатомічний розтин 18 трупів собак різного віку та породи. Відібрано фрагменти різних часток печінки для токсикологічного та морфологічного дослідження. Після проведення токсикологічного дослідження витяжки, отриманої з печінки та нирок собак, отримали позитивну якісну реакцію 3 ванадатом амонію та 3 саліциловим альдегідом, що свідчило про наявність в організмі ізоніазиду та його похідних. Для морфологічного дослідження відібрані взірці печінки фіксували в 10\% водному розчині нейтрального формаліну, рідині Карнуа і Буена. Після фіксації проводили зневоднення в етанолі зростаючої концентрації, ущільнювали в парафіні (Korzhevs'kij and Giljarov, 2010). Зрізи виготовляли на мікротомі MC-2 товщиною 7 мкм, фарбували гематоксиліном та еозином, за методикою Мак-Мануса, Перлса (Pirs, 1962). Виготовлені гістопрепарати розглядали під світловим мікроскопом Leica DM 2500 (Switzerland), фотофіксацію здійснювали фотокамерою Leica DFC450C з використанням програмного забезпечення Leica Application Suite Version 4.4.

\section{Результати досліджень}

Макроскопічно печінка у всіх досліджуваних трупів собак збільшена, краї заокруглені, неоднорідно забарвлена (від темно-вишневого до світлокоричневого кольору), в'ялої консистенції, на розрізі виділялась світла кров'яниста рідина, структура органу згладжена (рис. 1).

За гістологічного дослідження печінки собак, отруєних ізоніазидом, відзначали у різних частках органу вазодилатацію і переповнення вен, артеріол та внутрішньочасточкових капілярів зміненою кров'ю, різку проникність капілярів, плазморагію та дистрофічні процеси в гепатоцитах.

У одних собак відзначали, що стінки як центральних вен та судин портальних трактів різко розширені, деформовані внаслідок порушення їх цілісності і заповнені плазмою крові, а перипортальна сполучна тканина розпушена і набрякла. У стромі портальних трактів набряк і розширення просвіту лімфатичних судин. Виявлені зміни вказують на різку зміну тонусу судин і морфологічного складу крові (рис. 2).

Стінки артеріол тріад потовщені, їх структура гомогенна, розпушена, просякнута білками плазми крові, цитоплазма гладко м'язових волокон слабо еозинофільна, часто просвітлена, вакуолізована, ядра волокон набубнявілі або лізовані. Ендотелій артеріол і центральних вен порушений. Базальні мембрани центральних та портальних вен зруйновані, відзначали набубнявіння ендотеліальних клітин, просвітлення їх цитоплазми, лізис і рексис ядер та виражену їх десквамацію. Злущені ендотеліальні клітини вільно розміщувались серед плазми крові у просвіті судин. Виражені гістоструктурні порушення стінок центральних вен синусоїдної сітки сприяли інтенсивній гідратації, набуханню та розшаруванню аргірофільних волокон, а значне ураження їх стінок обумовлювало різкий вихід плазми крові (рис 3). Підвищення судинної проникності проявлялось деполімеризацією несульфатованих глікозаміногліканів стінок і міжваску- 
лярної сполучної тканини навколо артеріол і вен та фрагментацією і лізисом аргірофільних структур стінок мікроциркуляторного русла. Виявлені структурні зміни вказували на глибокі порушення усієї ангіоархітектоніки, строми та паренхіми органу. Різке розши-

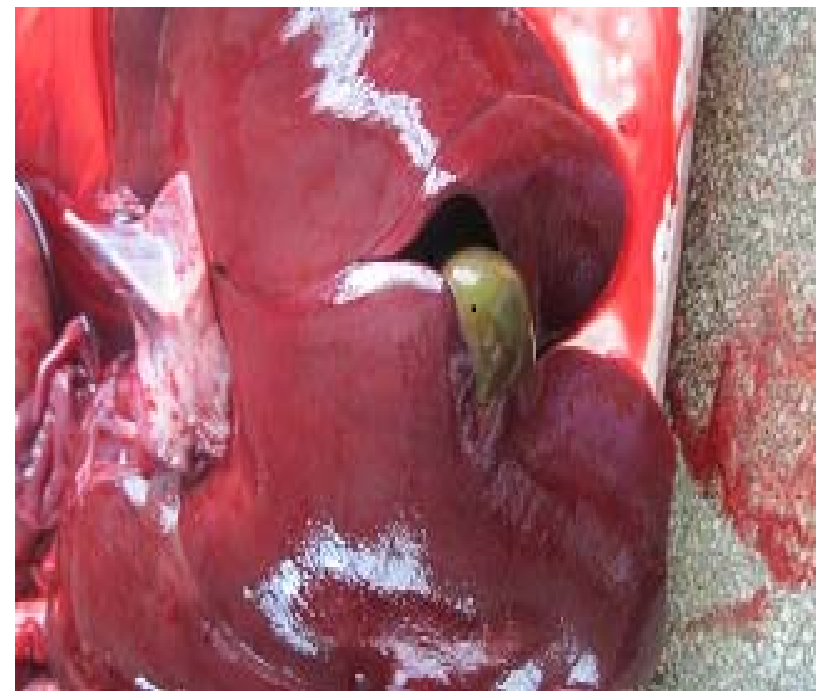

Рис. 1. Печінка собаки за отруєння ізоніазидом. Орган неоднорідно забарвлений, жовчний міхур переповнений жовчю

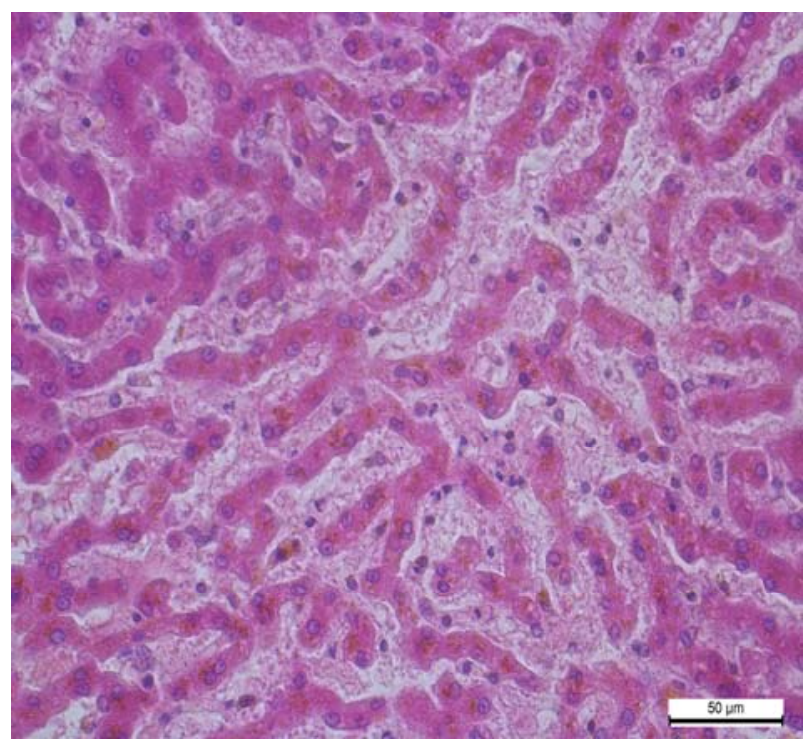

Рис. 3. Фрагмент часточки печінки. Синусоїдальні капіляри різко розширені і заповнені плазмою крові. Гематоксилін та еозин. Ок. 10, об. 40

Відомо, що у печінці, певна частина ізоніазиду одразу зазнає метаболічних процесів, а решта 3 током крові поширюються в інші органи і знову надходить по великому колу кровообігу в орган, де підлягає наступній метаболізації. У результаті постійної дії метаболітів у печінці відбувається патологічне руйнування клітин крові, гемоліз еритроцитів, порушення структур стінок судин, підвищення проникності і вихід плазми крові. Оскільки по синусоїдній сітці часточок протікає змішана кров від периферії до цен- рення синусоїдальної сітки, порушення структури ендотеліальних клітин синусоїдів відобразилось дискомплексацією печінкових пластинок, дилатацією i деформацією синусоїдів з утворенням осередків, заповнених плазмою (рис. 4).

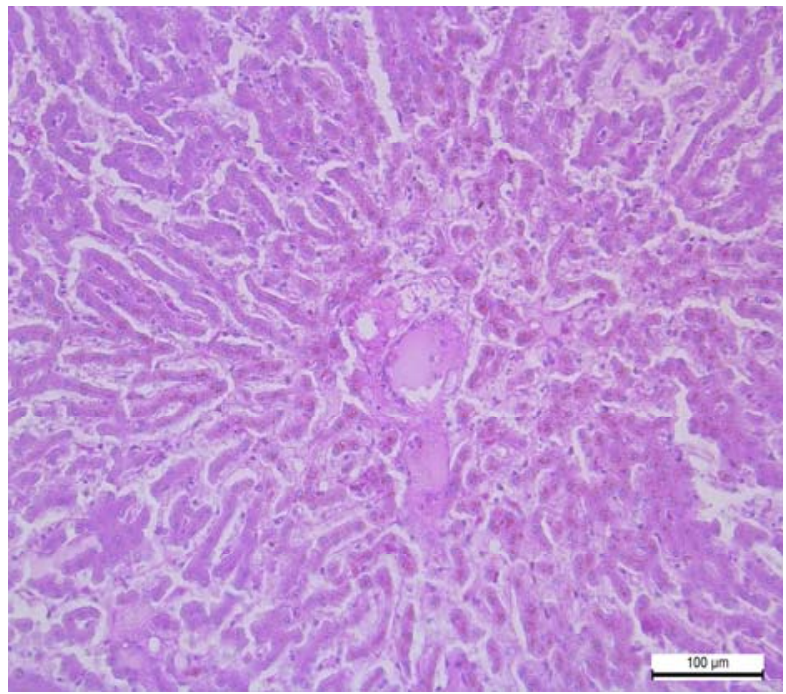

Рис. 2. Печінка. Просвіт вени та артеріоли портального тракту різко розширені, місцями зруйновані і заповнені плазмою крові Мак- Манус.

Ок. 10 , об. 20

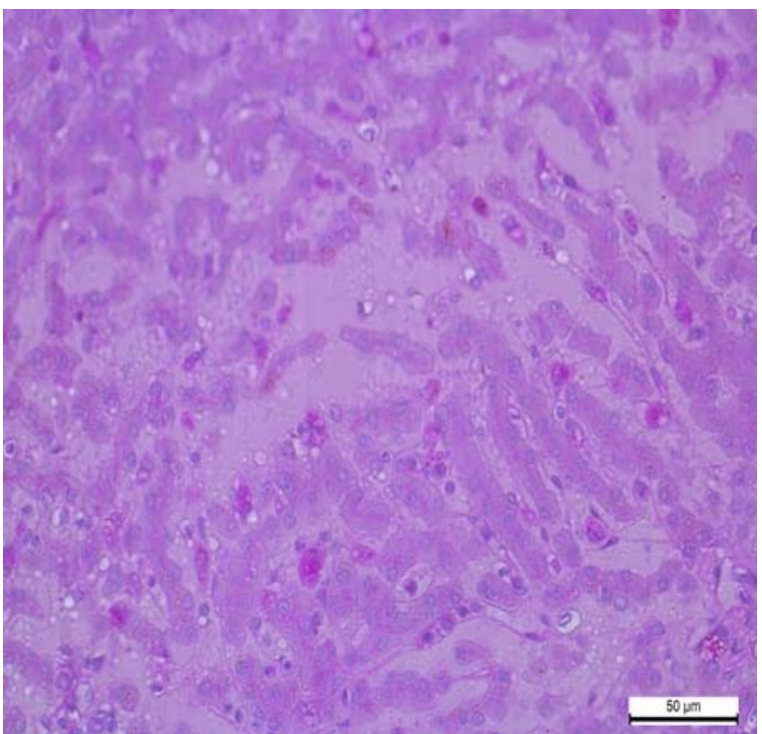

Рис. 4. Печінка. Деформація і дилатація синусоїдів печінки з утворенням осередків, заповнених плазмою крові. Мак-Манус. Ок. 10, об. 40

тральної вени, отруйні речовини, які містяться в ній легко потрапляють у міжклітинний простір, а потім крізь мембрани проникають у самі гепатоцити (Luzhnikov and Kostomarova, 1989).

На препаратах, забарвлених за Мак-Манусом, відзначали, що перисинусоїдальні просвіти також були різко розширені, просвітлені, не вбирали фарбу, що вказувало на відсутність в них плазми крові, яка повинна бути в нормі (рис. 5). У просвіті синусоїдів виявляли ніжно сітчасті фуксинофільні нитки, пооди- 
нокі злущені клітинні елементи, а у цитоплазмі гепатоцитів центролобулярних і перипортальних ділянок печінкових часточок - дрібні малинові гранули глікогену (рис. 6).

Внаслідок гемолізу еритроцитів в печінці, вивільнений гемосидерин захоплювався малочисельними макрофагами та поодинокими (функціонально актив-

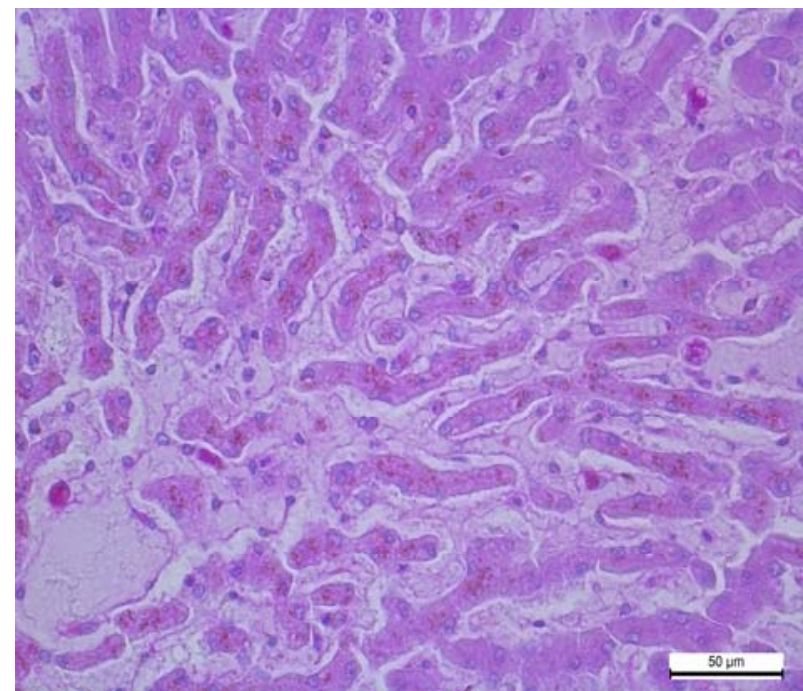

Рис. 5. Печінка. Стінка центральної вени і синусоїдальні капіляри різко розширені. Розширені (світлі) перисинусоїдальні просвіти. Мак-Манус. Ок. 10 , об. 40

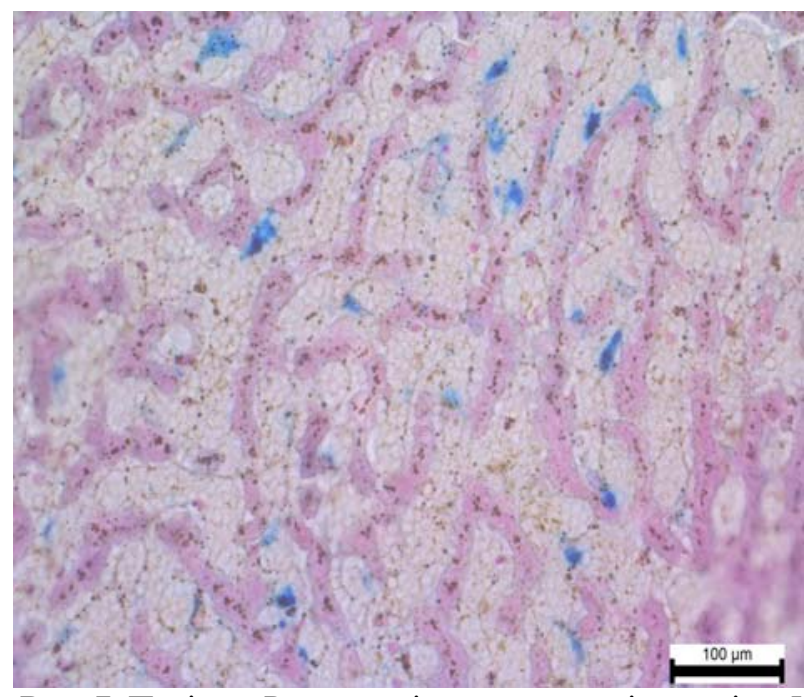

Рис. 7. Печінка. Розширені синусоїдальні просвіти. У цитоплазмі поодиноких ендотеліальних клітин сині нагромадження гемосидерину. Перлс. Ок. 10, об. 20

Виявлений в печінці гемоліз еритроцитів вказував на не тільки порушення обміну гемосидерину, а також і білірубіну. На препаратах, забарвлених гематоксиліном та еозином, в цитоплазмі гепатоцитів та у просвіті синусоїдів чітко візуалізувались темно-жовті та золотисто-жовті скупчення пігменту білірубіну (рис. 10).

У двох випадках, у загинувших від отруєння ізоніазидом собак, на тлі гострої застійної гіперемії, у перипортальнах ділянках відзначали діапедезні крововиливи (рис. 11). Просвіти судин і синусоїдів запо- ними) ендотеліальними клітинами. На гістозрізах, забарвлених за Перлсом, у цитоплазмі окремих ендотеліальних, поодиноких зірчастих клітин, в стінках судин виявляли нагромадження гемосидерину, який приймав голубувато-синє забарвлення, що вказувало на розвиток гемосидерозу (рис. 7 , рис. 8 , рис 9).

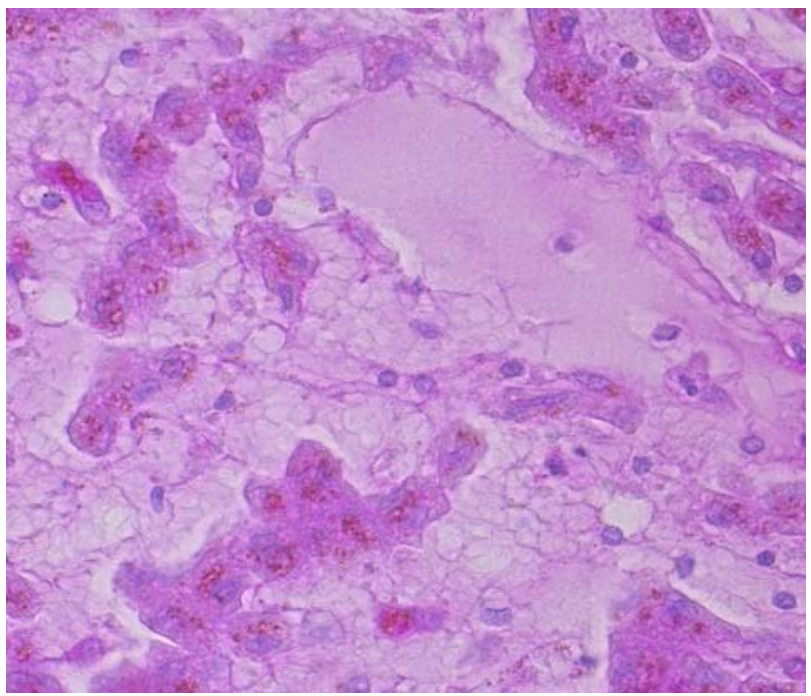

Рис. 6. Печінка. Різко розширена та зруйнована стінка центральної вени і синусоїдальних капілярів і заповнені плазмою крові. Гепатоцити містять дрібні гранули глікогену. Мак-Манус. Ок. 10, об. 40

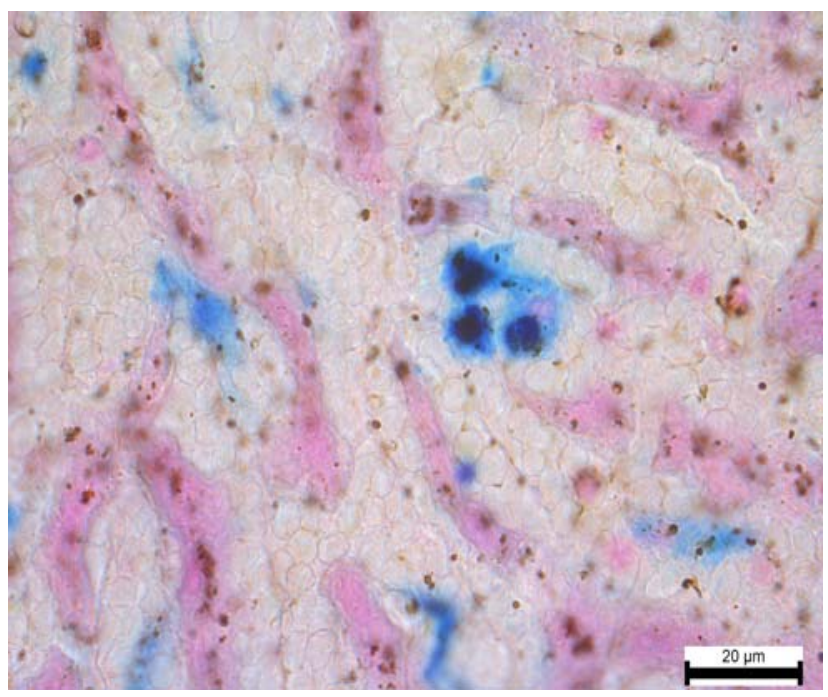

Рис. 8. Печінка. Розширені синусоїдальні просвіти. У цитоплазмі зірчастих клітин голубувато-синій пігмент гемосидерин. Перлс. Ок. 10, об. 100

внені лізованими еритроцитами. Межі між печінковими клітинами погано проглядались, цитоплазма мутна, еозинофільна. У набубнявілих ядрах гепатоцитів часто відзначали фрагментацію хроматину і краєві розміщення його грудок та нерідко просвітлену його центральну частину. Часто траплялись гепатоцити 3 лізованими ядрами та розпливчастими контурами, що вказувало на розвиток некробіотичних змін. Більшість зірчастих макрофагів знаходилась в стані лізису та пікнозу (рис. 12). 


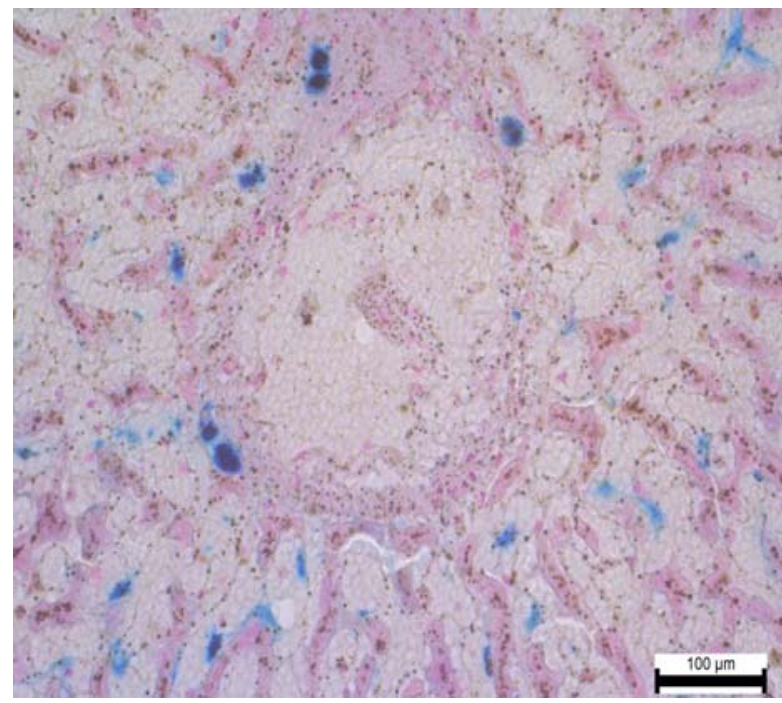

Рис. 9. Печінка. У цитоплазмі макрофагів стінки судин голубувато-синій пігмент гемосидерин. Перлс.

Ок. 10 , об. 100

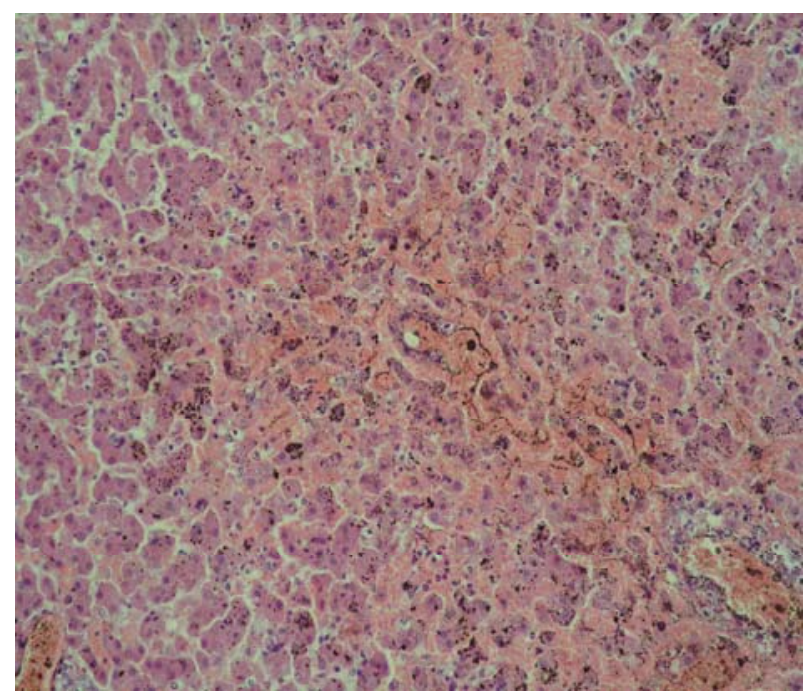

Рис. 11. Печінка. Діапедезні крововиливи.

Гематоксилін та еозин. Ок. 10, об. 20

\section{Обговорення}

Пусковим механізмом порушення гемодинаміки печінки собак було накопичення продуктів розпаду та обміну ізоніазиду, сполуки якого всмоктуються в шлунково-кишковому тракті та 3 кров'ю надходить через v. portae в печінку (70\%). Відомо, що основну роль в розвитку гепатотоксичності відіграє гідразин, що утворюється при метаболізмі ізоніазиду (Schwab and Tuschl, 2003).

Ізоніазид проявляє властивість заміщувати нікотинову кислоту в синтезі НАД з утворенням неактивних форм, блокувати піродоксинфосфатазу, яка перетворює піридоксин в його активну форму - піридоксальфосфат, а також зв'язувати останній з утворенням неактивного гідразонового комплексу (Kovalenko et al., 2004). Препарат, утворюючи комплекс $з$ піридок-

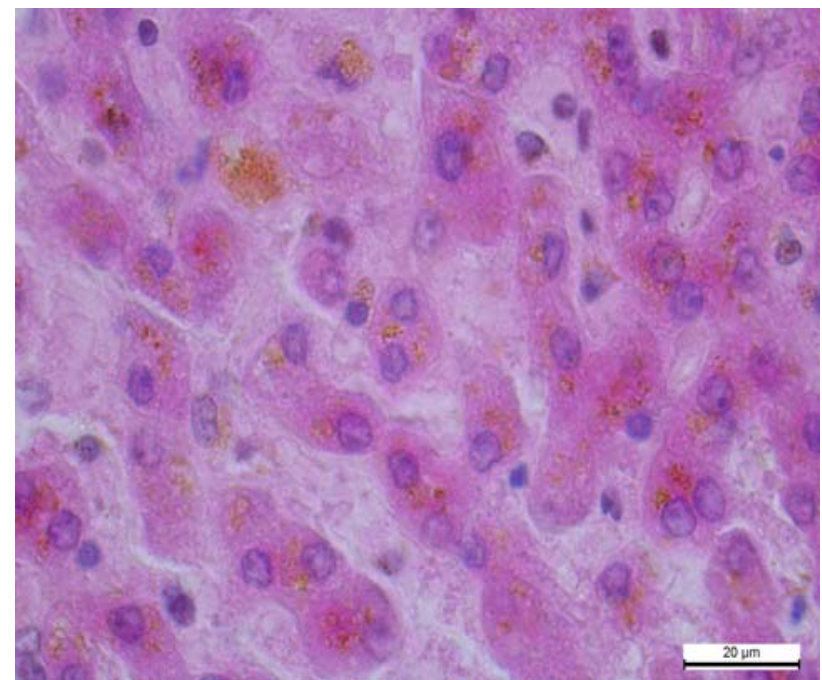

Рис. 10. Печінка. У цитоплазмі гепатоцитів та просвіті синусоїдів темно-жовті та золотисто-жовті скупчення пігменту білірубіну. Гематоксилін та еозин. Ок. 10, об. 40

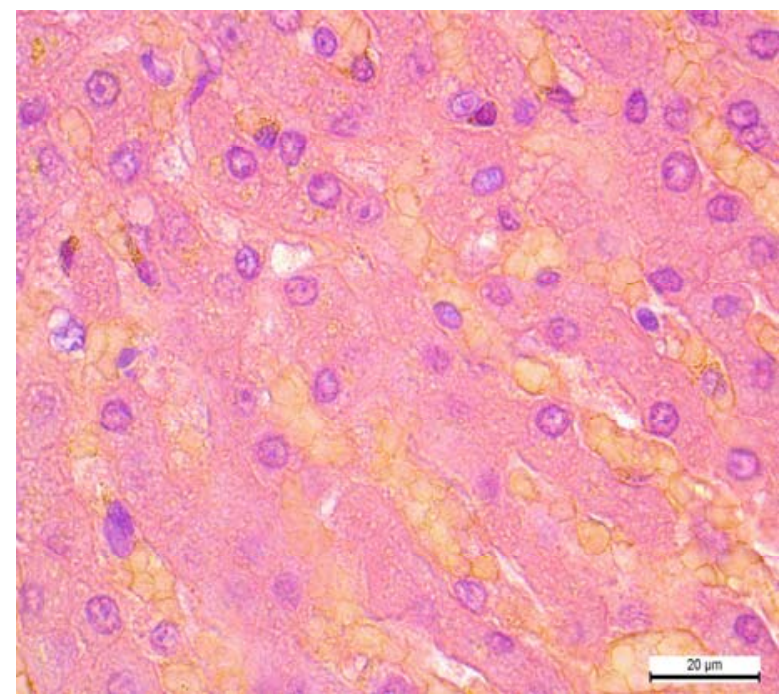

Рис. 12. Печінка. Лізовані еритроцити в просвіті синусоїдів. Гематоксилін та еозин. Ок. 10, об. 40

сином, інгібує синтез нікотинамідаденіндинуклеотиду (НАД), порушує процеси окислення і фосфорилювання 3 формуванням тяжкого метаболічного ацидозу. Внаслідок сповільненого утворення НАД порушується аеробне окислення глюкози, $\beta$-окислення жирних кислот, утворюється недостатня кількість АТФ, яка $є$ необхідною для окисно-відновлювальних процесів. Внаслідок цього у печінці розвивалась тканинна гіпоксія, погіршилось біологічне окислення, що зумовило порушення всіх обмінних процесів, що відзначилось порушенням внутрішньоклітинних структур клітин. На світлооптичному рівні в печінці собак це відобразилось глибоким порушенням всіх структур судинної системи, строми і паренхіми органу, що виразилось дилатацією, деформацією та руйнуванням стінок судин 3 превалюванням некробіотичних змін в ендотеліальних, купферівських клітинах, гепатоцитах і ери- 
троцитах. Виражений гемоліз еритроцитів у печінці собак супроводжувався відкладанням гемосидерину в цитоплазму макрофагів та білірубіну в гепатоцитах. На основі проведених морфологічних досліджень можна стверджувати, що похідні сполуки ізоніазиду в організмі собак володіють вираженою гепатотоксичною дією, зумовлюють різке порушення усіх обмінних процесів у клітинах печінки та різкі зміни крово- i лімфоообігу.

\section{Висновки}

Макроскопічно печінка у всіх досліджуваних трупів собак збільшена, краї заокруглені, неоднорідно забарвлена (від темно-вишневого до світлокоричневого), в'ялої консистенції, на розрізі виділялась світла кров'яниста рідина, структура органу згладжена.

Світлооптично у печінці більшості собак за отруєння ізоніазидом відзначали глибокі порушенням всіх структур ангіоархітектоніки, строми і паренхіми органу. Превалювали некробіотичні зміни ендотелію, дилатація і деформація центральних вен та синусоїдальної сітки з утворенням осередків, заповнених плазмою крові. Виражена дистрофія і некробіоз гепатоцитів та купферівських клітин поєднувались із гемолізом еритроцитів, що відобразилось відкладанням гемосидерину в цитоплазму макрофагів та білірубіну в гепатоцитах.

У поодиноких випадках, у печінці отруєних собак, виявляли гостру застійну гіперемію, діапедезні крововиливи у перипортальних ділянках та некробіотичні зміни в гепатоцитах.

\section{References}

Meyer, H., \& Mally, J. (1912). On hydrazine derivatives of pyridine carbonic acids. Monatshefte Chemie verwandte Teile anderer Wissenschaften (German), 33, 393-414.

Kotsyumbas, H.I., Dancovych, R.S., \& Vretsona, N.P. (2018). Pathomorphology and diagnosis of dogs poisoning with isoniazid. Scientific Messenger of Lviv National University of Veterinary Medicine and Biotechnologies. 20(83), 108-114. doi: $10.15421 /$ nvlvet8321.

Schmid, D.R., Lee, J.A., Wismer, T.A., Diniz, P.P.V.P., \& Murtaugh, R.J. (2017). Isoniazid toxicosis in dogs: 137 cases (2004-2014). JAVMA, 251(6), 689-695. https://www.ncbi.nlm.nih.gov/pubmed/28857697.

Hirtz, J. (1968). Les Methodes analytiques dans les recherches sur le metabolism des medicaments. Print book : French P., 153-154.

Korzhevs'kij, D.Je., \& Giljarov, A.V. (2010). Osnovy gistologicheskoj tehniki. SPb.: SpecLit, 16-20 (in Russian).

Pirs, Je. (1962). Gistohimija teoreticheskaja i prikladnaja. M.: Inostr. lit. (in Russian).

Luzhnikov, E.A., \& Kostomarova, L.G. (1989). Ostrye otravlenija. M.: Medicina, 155-156 (in Russian).

Schwab, C.E., \& Tuschl, H. (2003). In vitro studies on the toxicity of isoniazid in different cell lines. Human and Experimental Toxicology, 22(11), 607-615. doi: 10.1191/0960327103ht401oa.

Kovalenko, V.M., Voronina, A.K., Shaiakhmetova, H.M. ta in. (2004). Vplyv eks perymentalnoi polivitaminoi kompozytsii na protsesy detoksykatsii izoniazydu $\mathrm{v}$ pechintsi shchuriv za umov yoho tryvaloi dii. Eksperymentalna i klinichna medytsyna, 1, 20-23 (in Ukrainian). 